\title{
Genres and Styles: How to Disrupt a Market
}

\author{
Pragyan rath
}

\begin{abstract}
Markets have been studied through methods popularised by market research. Narrative Theory studies the formal properties of narratives. But narrative structures have market properties in terms of the value creation they develop in their consumption practises. What marketing research or narrative research has not leveraged is the inter-convertibility of both into each other, resulting in consumption patterns. Berger was the game changer in establishing the genre of narratives as producers of consumption needs through his definition of the consumer phenomenon called publicity. The Frankfurt School of Critical thinkers in Marcuse through his affirmative character of culture and Benjamin through envy / aura discourse have discussed the logic of mass cultural behaviour for developing distinctive identities. Sociologist Bourdieu has discussed various forms of economic capital in the form of cultural capital and their forms. Using the inter-disciplinary interconnectivity of BergerBourdieu-Marcuse-Benjamin, through the research method of theoretical speculation, the author attempts to develop schematics of consumption investigation called the Genre GPS. Through the method of the global positioning system, we can track travellers. Through the Genre GPS we can track the consumption need developing / saturating / disrupting the mass consumption pattern in a market context, where the consumption need can be identified or developed or transitioned from one type to another from the kind of narrative or the genre of story-telling that is being used for representation in the given system. Thus, the attempt in the paper is to develop the conversion of genres of representation into economic value creations.
\end{abstract}

Key Words: Publicity, Narrative Genre, Landscapes, Affirmation, Cultural Capital, Aura, Envy, Markets.

Type of Paper: Theoretical / Conceptual

\section{Introduction}

It was John Berger in his iconic British Broadcasting Corporation (BBC) episodes and in the eventual best seller - Ways of Seeing (1972) - devised a genre template for narratives. What makes his template of narrative genres insightful and useful are the criteria of genre division. In the history of narrative theory, Berger hardly makes the cut because the criteria for genre division have more to do with formal properties of narrative structure. But with Berger, there is a marked departure in the same. His division parameter highlights a very crucial point of departure - the economic valorisation that the genre intends to exchange its artistic form for, and the intent here is not the story or the methods of the story being told - the intent is more to do with the economic value the story and its form intend to fulfil. To understand the economic value of narratives, we have to go through the history of critical / literary theory to understand where the valorisation 
intent comes from. Critical theory posits two strong thinkers who play a significant role in helping the author reposition Berger's genre template as an economic template of concern.

\section{Critical Theory: A History of Sorts}

Critical Theory has come a long way in helping to understand art and its types as market evaluations. It started with Marx in a big way, and Frankfurt School of Critical Thinking institutionalised the criteria of art as an economic tool of consumption and governance. There are two Frankfurt thinkers who are significantly important in this paper's scheme of things. They happen to be Herbert Marcuse and Walter Benjamin.

\section{Marcuse and the Affirmative Character of Culture}

Herbert Marcuse in his Negations (1968) discusses the 'affirmative character of culture' function. He states that a culture takes a utilitarian view of art. Art is understood as a parallel universe, a possible world, an alternate reality, wherein lie higher values of the human world, the conditional options, the wishful thinking, and the grand narratives - the untouched parameters of human conduct of goodness, virtue and beauty. Art functions as that wishful world where we as human beings may enjoy our greater order of existence - the existence of goodness. But once out of that world, back into the economic transactions of daily lives, we continue with our transactional and mundane nature of existence. The contradiction is what is interesting for us. The very same economic forces produce the composition of virtues in that possible world - the world of art where everything is beautiful, good and true, and a far cry from the world of economics, where everything is ugly, brutal and utilitarian. Hence, to maintain the human faith in the better form of human consciousness, art functions as the unifying technology that helps affirm the culture to an artistic consensus of human virtues, but alas an artistic one. Diagrammatically, figure 1 explains the affirmative character of culture.

Figure 1: Affirmative Character of Culture
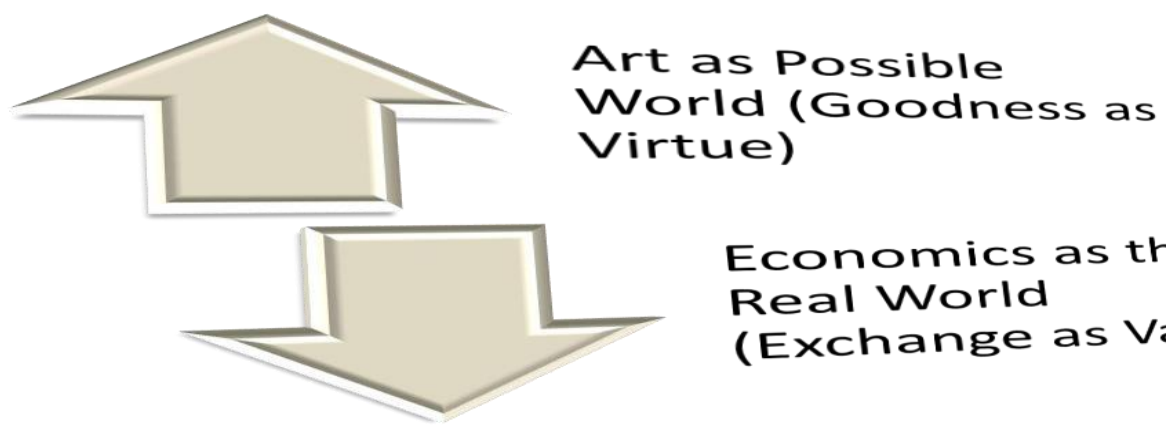

Economics as the

Real World

(Exchange as Value) 


\section{Benjamin and the Aura vs. Envy Phenomenon}

Walter Benjamin in "The Work of Art in the Age of Mechanical Reproduction" discusses the social production of sentiment through the work of art - predominantly, he identifies two kinds. He says aura is a social condition of collective feeling that emerges when the object of aura has a halo around it - the object is beyond reach, and that is because it is enigmatic, distanced and its means of production invisible. In other words, the object of aura is apparently there for intrinsic qualities within it - qualities that only the object of aura can have, and thereby bestow upon the object a unique, and authentic and distinctive quality of existence that can only be admired but not possessed by the onlookers. On the other hand, there is envy. Envy is a social collective feeling that emerges for an object of some altitude, but more so because of the wish to displace it. The object is not at the altitude because it has intrinsic virtue, but because the technology it has used to create value for itself is the reason for its exalted altitude. In other words, the means of production of its animated social position is apparently evident. Thus the onlooker can aspire for the same, with the conditional criterion of success being the tool or the possession of the material value that got the object this grand social position as such. Now, what happens to the object of envy? It evaluates its position in terms of the social envy that is produced for it by the paradoxically aspirational class of people - the very class who think they can displace the object of envy by acquiring the material benefits, the acquisition of which got object to this position. On the other, the object basks in the envy creation because it feels validated of its successful social position through the acquisition of materiality that gives it this position, and yet, the materiality is merely the technology; it is more the production of envy that creates value for the position - the position is not aspirational if it is not enviable! Hence, to be aspirational, the position has to appear achievable, and yet, to be enviable, the position has to delude the acquiring of it, and the affirmation of not acquiring it has to come from the narrative that the lack of acquiring the material technology is the only reason for the inequality. Figure 2 depicts the complex inverse proportion of the aura and envy social production of value creation.

Figure 2: Aura and Envy Social Production of Value Creation

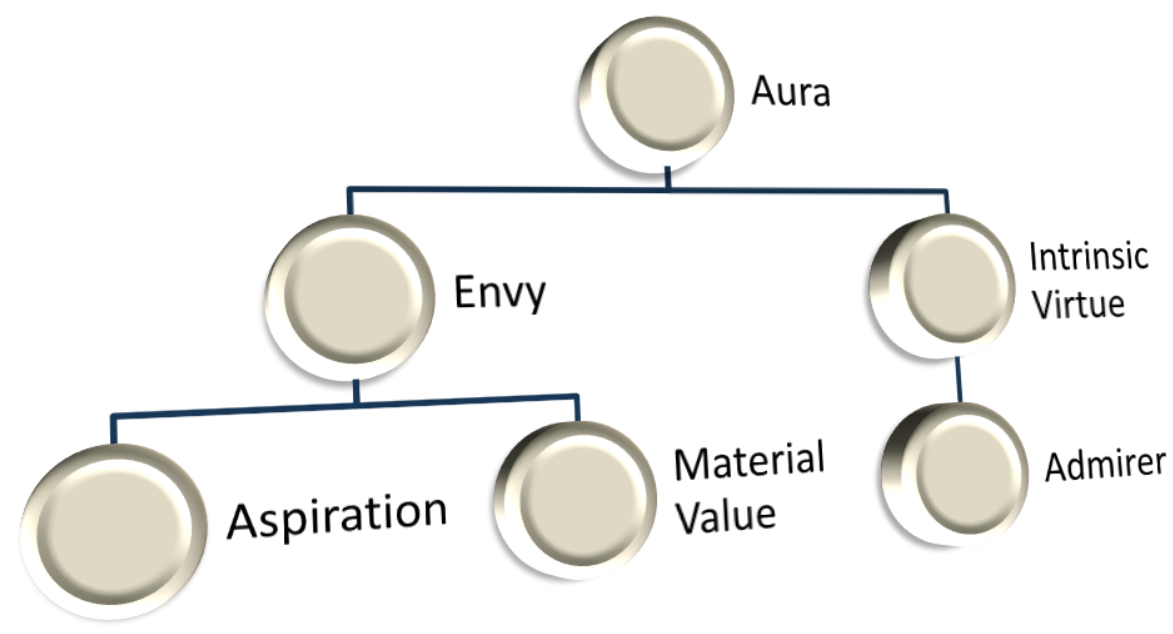




\section{From Critical Theory to Sociology to Economics}

It was Pierre Bourdieu who revolutionised the Marx notion of economic capital into cultural capital in his oft quoted "Forms of Capital" (1986). Culturally, sociologically and otherwise, it all started with the feudal system, and art and high art was the possession of the acquirers of the economic capital. Thus people with art were people with cultural capital: artistic value was directly proportional to economic value. The rich had art embodied in their life, their way of living, and this embodiment was translated as legacy through generations. This is the least transactional form of culture; it is the most preserved form. This is embodied capital. With the bourgeoisie capturing the market and thereby leading to the collapse of the aristocrats, cultural capital started becoming transactional in terms of obtaining objects of value - this started being called the objectified capital. With time new institutions developed, and these institutions defined values - this came to be institutionalised capital. With the era of technology entering and disturbing class systems, what we get is the prominence of cultural capital - what was originally an add-on to economic wealth or a by-product of it, was now a substitute for it. So, social status was determined by the cultural capital and not necessarily the economic capital, or so was the shift from economic positioning to a cultural positioning. Figure 3 represents the transition of economic capital into cultural capital.

Figure 3: Transition of Economic into Cultural Capital Forms

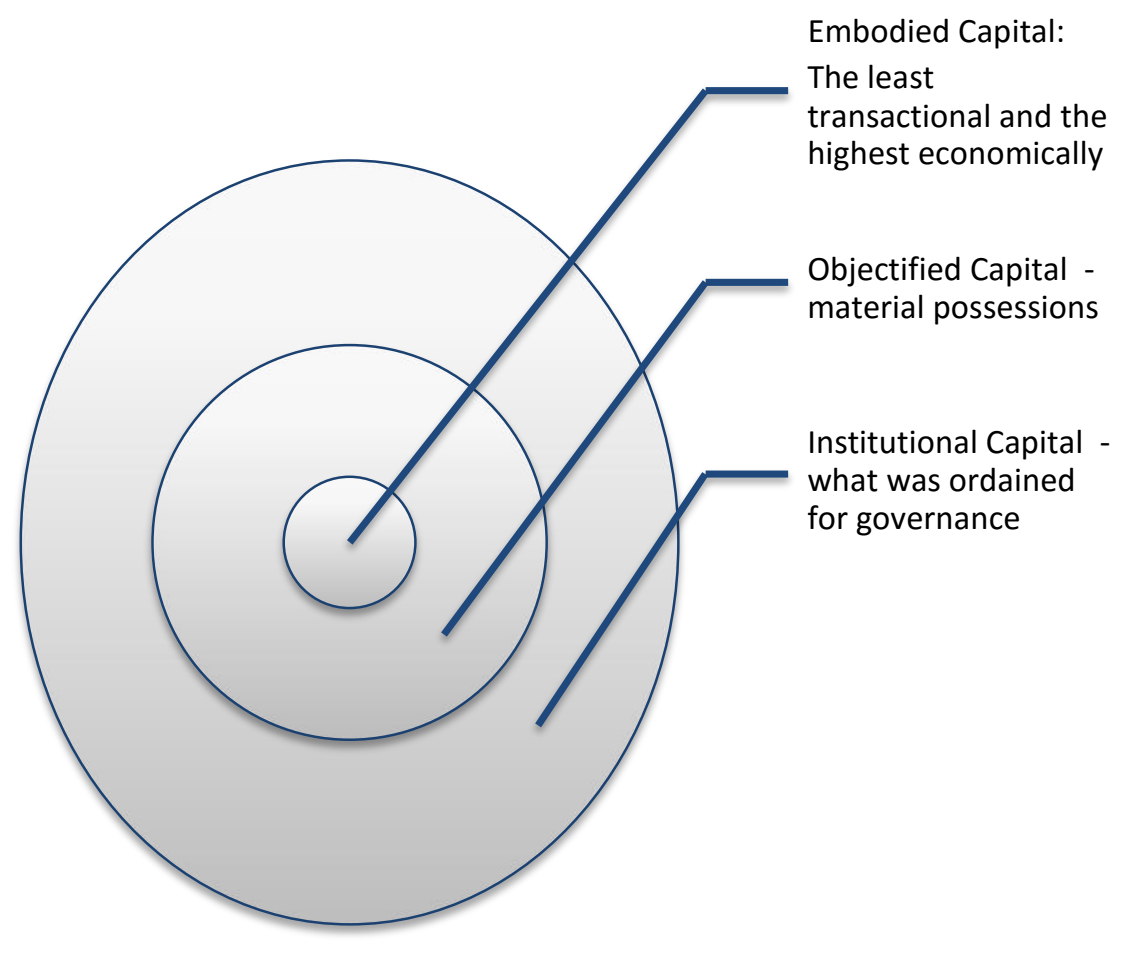




\section{Berger and Narrative Genres}

Berger identified from the representation forms of the foundational era of consumerism, more popularly known as the Age of Reason, the prominent forms of narrative representations through the most famous medium of representation then - the oil paintings. He found the parallel of these genres in the more modern form of commercial representations in the more modern form of consumerism with the more modern tool of representation - cheap colour photography in commercials. The highest form of genre was the History paintings. The rich patrons chose artists to represent them through legacy or mythological or historical episode, but the intention was not to represent these legacies, but to translate the legacy as a representative of the patron himself. In other words, the mythological figure represented the patron in the 'ideal' world of art. Thus, the genre depicted the ideal pose. The 'icon' was an idealised representation of the spectatorbuyer. Then came the portraiture, where the personality was surrounded with and by his objectified capital. Thus, the material around her added to her social status - it is bureaucratic pose. S/he was individualised and hence depicted the rise in economic category, but at the same time distanced - s/he looked through you, just like Benjamin's envy. Then, the genre representations. These were cheaper forms of idealised community / collective representations of the mass - the common people - who have not made it up the economic ladder, but the hope in human goodness is very much alive and strong. These depicted the sentimental pose - 'we are happy working hard and praying and God will take care of us'. The sentimental pose adequated survival rather than disrupt systems through rebel forms of upheaval. Then, came the landscapes with the property pose - ownership and the mileage one can get from what the community thinks is good ownership. Even the livestock and architecture were represented in a manner that showcased ownership - as if animals were mere properties. Then, there were the still lives. These were only objects, but objects presented as objects of art. Thus, the concupiscence pose, or the pose of $\sin -$ but a lesser sin. This cheap possession of objects as art objects was a depiction to the world of the phenomenon of the conspicuous consumption. Figure 4 illustrates the hierarchy of genres.

Figure 4: Hierarchy of Genres

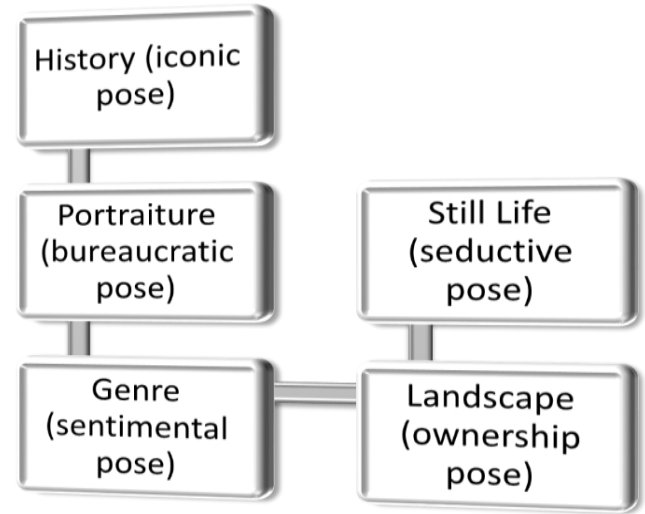




\section{Language of Publicity - Berger}

It was Berger who developed the social construct of the greatest tool of modern mode of representation - the language of consumerism - publicity. Publicity is the language of economic capital, albeit deferred. Unlike oil paintings, advertisements showed not what is there today, but what upon buying into their depicted materiality will make avail the transformation of the way of living of the spectator-buyer from his humble existence in the real world to the existence in the ideal world. Thus, publicity is nothing but deferred economic capital. And this condition of deferred economic capital is nothing but manufacture of mass social envy. And this condition of being looked at enviously by the masses is called glamour. Publicity converts personal envy into mass envy through the manufacture of glamour. Figure 5 establishes the grammar of publicity.

Figure 5: Grammar of Publicity

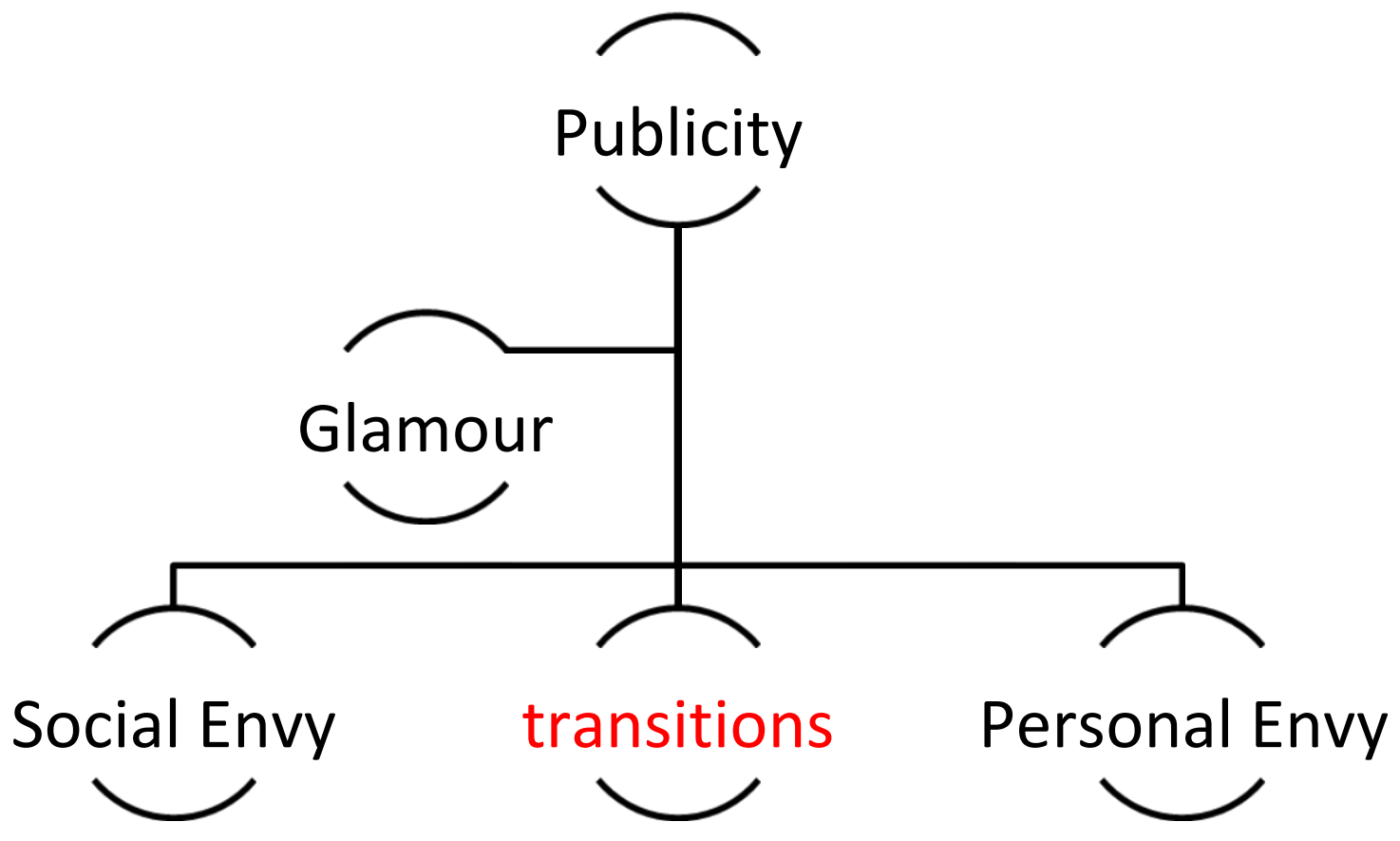

\section{Research Proposition: Scope of a Nuanced Form of Representational Strategy}

Berger mentioned how a personal emotion transitions into a collective mass emotion, and the manufacture of that emotion at a mass level thus becomes the means of crowd control. Now let us transition crowd control into Marcuse's affirmative character of culture, mass emotion into the Benjamin aura-envy phenomenon, and transitioning the mass emotion into economic emotion by the artistic pose, as cultural capital, and the entire transition brought about by the narrative genre type. Thus, we get a nuanced form of representational strategy, where the type of 
representation creates a mass emotion, which is economically viable. So, in history paintings, the idealised pose creates a social function called aura-glamour, and thereby, a substitute of economic capital - embodied capital. This is affordable by the rich spectatorbuyer. Table 1 shows the correspondence map of all the connections. We call this the Affirmative Consumption Segmentation.

Table 1: The Consumption Segmentation

\begin{tabular}{|c|c|c|c|c|c|}
\hline \multirow[t]{2}{*}{ Genre } & \multirow{2}{*}{$\begin{array}{l}\text { Spectator } \\
\text { Buyer }\end{array}$} & \multicolumn{3}{|c|}{ Affirmative Character of Culture } & \multirow{2}{*}{$\begin{array}{l}\text { Personal } \\
\text { Emotion } \\
\text { into Mass } \\
\text { Emotion = } \\
\text { Glamour }\end{array}$} \\
\hline & & $\begin{array}{l}\text { Possible } \\
\text { World }\end{array}$ & Referent & $\begin{array}{l}\text { Symbolic } \\
\text { Pose }\end{array}$ & \\
\hline History & $\begin{array}{l}\text { Social } \\
\text { Capital } \\
\text { (rich) }\end{array}$ & $\begin{array}{l}\text { Icon } \\
\text { History/ } \\
\text { Legacy }\end{array}$ & You & $\begin{array}{l}\text { Idealized } \\
\text { view to } \\
\text { support } \\
\text { own } \\
\text { view: } \\
\text { Idealised } \\
\text { Pose }\end{array}$ & Aura \\
\hline Portraiture & $\begin{array}{l}\text { Social } \\
\text { capital } \\
\text { (upper } \\
\text { middle } \\
\text { class, } \\
\text { rich, } \\
\text { gradually } \\
\text { middle } \\
\text { class) }\end{array}$ & $\begin{array}{l}\text { Your } \\
\text { Consoledated } \\
\text { status with } \\
\text { all } \\
\text { things you } \\
\text { own } \\
\text { visually } \\
\text { there with } \\
\text { your } \\
\text { presence }\end{array}$ & You & $\begin{array}{l}\text { Bureau- } \\
\text { cratic } \\
\text { Pose }\end{array}$ & Envy \\
\hline
\end{tabular}

\begin{tabular}{|l|l|l|l|l|l|}
\hline Genre & $\begin{array}{l}\text { Mass } \\
\text { Market }\end{array}$ & $\begin{array}{l}\text { If not the } \\
\text { market, a } \\
\text { higher power } \\
\text { will take care } \\
\text { of you }\end{array}$ & $\begin{array}{l}\text { You } \\
\text { (through the } \\
\text { idealised } \\
\text { pose of your } \\
\text { community) }\end{array}$ & $\begin{array}{l}\text { Sentimen } \\
\text {-tal }\end{array}$ & Pose \\
& & & \\
\end{tabular}


 \\ HUMANITIES \& SOCIAL SCIENCE}

\begin{tabular}{|l|l|l|l|l|l|}
\hline & $\begin{array}{l}\text { Mass } \\
\text { Market }\end{array}$ & $\begin{array}{l}\text { Celebration of } \\
\text { private } \\
\text { property }\end{array}$ & $\begin{array}{l}\text { You (though } \\
\text { more focus } \\
\text { on what you } \\
\text { own, } \\
\text { particularly } \\
\text { land and } \\
\text { architecture) }\end{array}$ & $\begin{array}{l}\text { Utility } \\
\text { Pose } \\
\text { Conspicu } \\
\text { ous } \\
\text { Consump } \\
\text { tion }\end{array}$ & Mileage \\
\hline Landscape & $\begin{array}{l}\text { Mass } \\
\text { Still Life }\end{array}$ & $\begin{array}{l}\text { Common } \\
\text { object } \\
\text { converted into } \\
\text { Object d'Art } \\
\text { (object of art) }\end{array}$ & $\begin{array}{l}\text { Your artistic } \\
\text { through }\end{array}$ & $\begin{array}{l}\text { Seductive } \\
\text { Pose }\end{array}$ & $\begin{array}{l}\text { Concupiscence } \\
\text { (lesser sin } \\
\text { which may be } \\
\text { forgiven) }\end{array}$ \\
& & & & \\
\hline
\end{tabular}

In a consumer society, social function of art is glamour, and thus, if we can map the kind of glamour with the kind of narrative genre, then we can map the potential capital developed for a consumer market. Table 2 illustrates the value of glamour. And this value creation also depicts the hierarchy of the economic aspirational sectors.

Table 2: Value of Glamour

\begin{tabular}{|l|l|l|l|}
\hline Genre & $\begin{array}{l}\text { Function of } \\
\text { Art } \\
\text { = Glamour }\end{array}$ & $\begin{array}{l}\text { What is the status of the } \\
\text { Means of Production and } \\
\text { the fate of the Aspiration of } \\
\text { the economic segment }\end{array}$ & $\begin{array}{l}\text { Corresponding Capital } \\
\text { Formation }\end{array}$ \\
\hline History & Aura & $\begin{array}{l}\text { Not visible, neither the tool } \\
\text { nor the outcome easily } \\
\text { Exchangeable }\end{array}$ & Embodied Capital \\
\hline Portraiture & Envy & $\begin{array}{l}\text { Visible, the tool is mass } \\
\text { reproduced but not the } \\
\text { outcome, not necessarily, but } \\
\text { economic segment may or } \\
\text { may not change }\end{array}$ & Objectified Capital \\
\hline Genre & $\begin{array}{l}\text { Sentimentali } \\
\text { sm } \\
\text { (esteem) }\end{array}$ & $\begin{array}{l}\text { Not visible, tool is grand } \\
\text { narratives, the outcome is not } \\
\text { mass reproducible (you stay } \\
\text { in the same economic } \\
\text { segment) }\end{array}$ & Institutionalized Capital \\
\hline
\end{tabular}




\begin{tabular}{|l|l||l|l|}
\hline Landscape & $\begin{array}{l}\text { Mileage } \\
\text { (esteem) }\end{array}$ & $\begin{array}{l}\text { Visible, limited } \\
\text { reproducibility } \\
\text { (economic segment may } \\
\text { change) }\end{array}$ & Institutionalised Capital \\
\hline Still Life & $\begin{array}{l}\text { Seduction } \\
\text { (esteem) }\end{array}$ & $\begin{array}{l}\text { Visible, mass reproducible, } \\
\text { but you stay in the same } \\
\text { economic segment }\end{array}$ & Objectified Capital \\
\hline
\end{tabular}

\section{Findings: The Capitalist vs. the Post Capitalist Contrast}

Let us map the Affirmative Strategy and the Value Creation of Publicity with contemporary commercials in different industry / market domains, as represented in Table 3.

Table 3: Publicity through Affirmative Consumption

\begin{tabular}{|l|l|l|l|}
\hline Publicity & Glamour & Genre & Industries \\
& Aura & History & $\begin{array}{l}\text { Niche } \\
\text { Products / } \\
\text { Royalty }\end{array}$ \\
& Envy & Portraiture & Jewellery, Lux \\
& Sentimentalism & Genre & $\begin{array}{l}\text { Bajaj / } \\
\text { Insurance / } \\
\text { Chetan Bhagat books, Dove } \\
\text { soap as pitched against Lux } \\
\text { soap }\end{array}$ \\
\hline & $\begin{array}{l}\text { Mileage } \\
\text { (esteem) }\end{array}$ & Landscape & $\begin{array}{l}\text { Tourism, } \\
\text { Acquisitions }\end{array}$ \\
\hline $\begin{array}{llll}\text { Seduction } \\
\text { (esteem) }\end{array}$ & Still Life & e-commerce \\
\hline
\end{tabular}

Generally niche and luxury products have the aura built around them through their legacy / historical / mythological projection. The British royalty still uses its embodied capital to project its superior existence to a mass spectator. Jewellery commercials use 'envy' to establish their social position. An interesting episode is the contrast between the famous Lux and Dove soap representation. Lux soap uses big celebrities to position itself with envy. If the spectator buyer uses Lux, s/he will have the life that the celebrity has. But in today's era of post capitalism, the impact of the celebrity as aspirational may not work on many audience segments. Dove for instance positions the normal women through its genre narrative of sentimentalism - 'we are beautiful as we are'. Or, say, Chetan Bhagat brought about a revolution by writing like and for the common people - again genre sentimentality. Tourism was more into the kind of landscapes the destination owned. Dan Brown projects landscapes and genres in his best sellers. Post- 
acquisition narratives are on the landscape of products and services available, for consumers now to re-own. And e-commerce sites are full with their countless glorious seductively posed objects.

But what about populations who are no longer enamoured by celebrities, or who do not buy into sentimental lies. The disruptive glamour that got introduced into the market happens to be selfactualisation needs - the need to search for one's true identity - the need to be different from even celebrities (both aura and envy), and also from your community (genre).Self-actualisation as a need stems when the economic growth as pointed out in table 3 starts disrupting the set hierarchy. As mentioned, embodied capital loses its sheen, envy is now mass reproducible, and hence everyone has access to the material-tool that would eventually propel the spectator-buyer into a better economic position. So, what happened to people in the upper crust of the economic strata who have their aesthetic pose and hence their intrinsic cultural capital now appropriated by the lower economic segments, and by this mass appropriation and hence class neutralisation, these consumers are left to fend for themselves in a world of clones, robots and mass neutralisation and standardisation and homogenisation. Their differential sense of being unique and exclusive is lost upon the market - hence here we have a personal emotion that has the potential for mass reproduction - a new breed of emotion - that can disrupt the hierarchy of aura and envy - and this is self-actualisation. Thus, brands come in with symbolic poses which have abstract representations, and these

abstract representations 'only' lend themselves to these 'segregated' and 'ghettoed' people, who, time and technology and economics were passing over. So, here is the new Disruptive Technology in Affirmative Consumerism as illustrated by Table 4.

Table 4: Disruptive Conversion of Aura/Envy into Self Actualisation = Disruptive Affirmative Strategy

\begin{tabular}{|l|l|l|l|l|l|}
\hline Genre & $\begin{array}{l}\text { Old } \\
\text { Glamour }\end{array}$ & $\begin{array}{l}\text { Social } \\
\text { Gap for } \\
\text { Leveragin } \\
\text { g } \\
\text { Disruptio } \\
\text { n }\end{array}$ & $\begin{array}{l}\text { New } \\
\text { Disruptive } \\
\text { Glamour } \\
\text { (new social } \\
\text { condition) }\end{array}$ & $\begin{array}{l}\text { New Symbolic } \\
\text { Pose }\end{array}$ & $\begin{array}{l}\text { Correspondi } \\
\text { ng } \\
\text { Capital } \\
\text { Formation }\end{array}$ \\
\hline History & $\begin{array}{l}\text { Aura no More } \\
\text { for embodied } \\
\text { capital }\end{array}$ & $\begin{array}{l}\text { People are } \\
\text { climbing } \\
\text { economic } \\
\text { segments } \\
\text { at } \\
\text { least } \\
\text { through } \\
\text { cultural } \\
\text { capital }\end{array}$ & $\begin{array}{l}\text { Self } \\
\text { Actualise } \\
\text { (empowerm } \\
\text { ent) }\end{array}$ & $\begin{array}{l}\text { Gesamtkunstwe } \\
\text { rk Absolut } \\
\text { experience, } \\
\text { aesthetic } \\
\text { experience, } \\
\text { relation to } \\
\text { the brand, to } \\
\text { each }\end{array}$ & $\begin{array}{l}\text { All forms of } \\
\text { capital }\end{array}$ \\
\hline
\end{tabular}




\begin{tabular}{|l|l|l|l|}
\hline $\begin{array}{l}\text { Portraitu } \\
\text { re }\end{array}$ & $\begin{array}{l}\text { Envy is } \\
\text { useless } \\
\text { Now as tools } \\
\text { of }\end{array}$ & $\begin{array}{l}\text { Dilution of } \\
\text { that which } \\
\text { earlier } \\
\text { caused } \\
\text { distinctio } \\
\text { envy are } \\
\text { massreproduce } \\
\text { d }\end{array}$ & $\begin{array}{l}\text { other, to their } \\
\text { life- } \\
\text { world and to } \\
\text { themselves }\end{array}$ \\
\end{tabular}

\section{Birth of the New Genre: How to Disrupt the Consumer Market through Symbolic Narrative}

The clown character in the Batman series is the greatest of abstract symbols - it refers to itself. So, abstract advertising use abstract language to make sense to the consumer segment looking for distinction from mass reproduction. And hence this new form of language that is not mass reproducible elevates the distinctive ability of interpretation. Hence, the envy and the aura is converted into a self-actualised symbolic value - where the need is to 'experience' one self in the complete act of making meaning, an 'experience' that only art can bring. The German word is Gesamtkunstwerk - the complete aesthetic experience. And yet, the winning hand in value creation is the institutionaliser of the Gesamtkunstwerk.

\section{Research Proposition: Gesamtkunstwerk Value Creation for Sustenance in OverSaturation}

When the mass saturation is reached, value differentiation is a requirement, and the value differentiator will reap profits through identification of the affirmative needs of the consumer segment. Once the needs are identified, the existing need is transitioned to the disruptive affirmation positioning through corresponding narrative styles. Thus, in a system, the value creator is the need differentiator, the means of value creation is transition of glamour, and the consumers are the spectator-buyers whose needs the transitional glamour converts into aspirations and thereby in a system of economic neutralisation, is produced genres of narratives with corresponding economic values. Thus, every system has an underlying economic logic of disruption/sustenance, and that is what we call the affirmative logic of the publicity template. Figure 6 illustrates the Genre-Publicity Template for Value Creation, or what we can nickname as the Genre GPS. 
Figure 6: Genre GPS

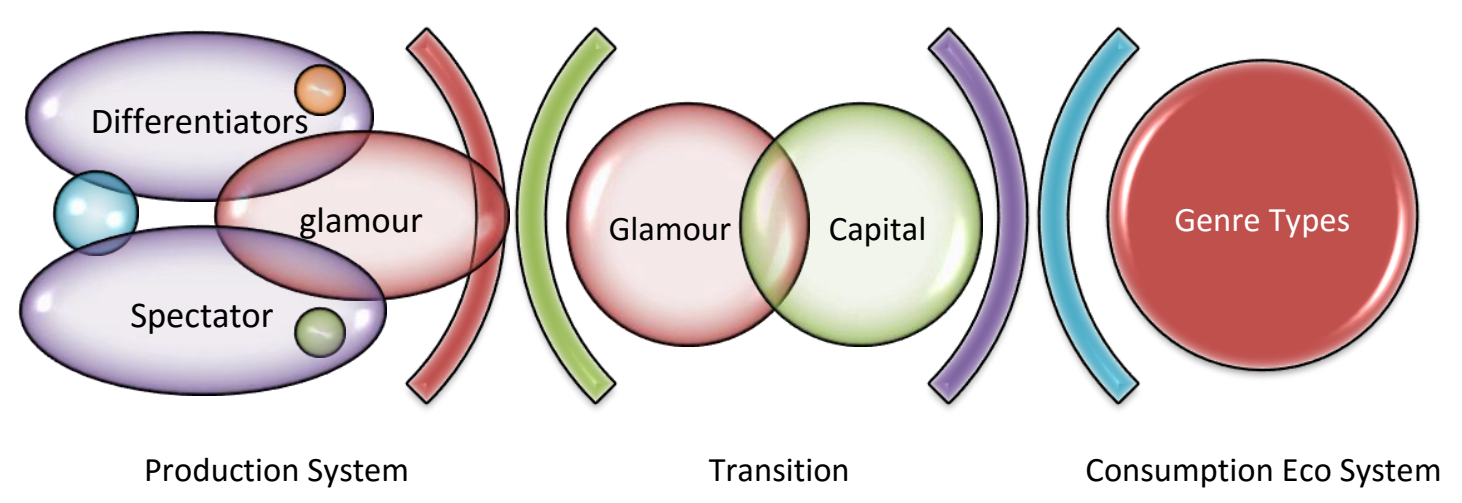

\section{Future Research Possibilities}

The Genre GPS explains the unlimited possibilities of consumer study and marketing and branding and value creation. What kind of narrative would unfold what kind of mass emotion, and hence what kind of mass emotion produces what kind of social phenomenon in terms of the kind of glamour created, and with the kind of glamour created, the kind of capital formulation developed - this identification of the reigning form of cultural capital will project two circumstances for the differentiator:

(a) How the current cultural capital reigns supreme

(b) Whether the current cultural capital is on the verge of disruption in terms of the saturation of social emotion

(c) On identification of saturation, bring in the disruptive technology of genre production.

Thus the Genre GPS will help pitch the narrator-producer as the market surplus value creator through the conversion of narratives into economic capital. To add to the Genre GPS method, one has to develop the methodology of narrative scanning and analysis, and that is the next step to market analysis.

\section{References}

- Benjamin, W. and Underwood, J. 2008. The Work of Art in the Age of Mechanical Reproduction. London: Penguin.

- Berger, John, and Michael Dibb. 1972. Ways of seeing. [London]: BBC Enterprises.

- Bourdieu, P. (1986). The Forms of Capital by Pierre Bourdieu 1986. [online] Marxists.org. 
https://www.marxists.org/reference/subject/philosophy/works/fr/bourdieuformscapital.htm [Accessed 4 Apr. 2015].

- Marcuse, Herbert. 1968. Negations: Essays in Critical Theory. Free Association Books. 